braska, 217N Love Library, Lincoln, NE 685880410 .

\section{Women's Studies Section}

Vice-Chair/Chair-Elect: Patricia A. Kreitz, Head, General Reference Services, $208 \mathrm{Main} \mathrm{Li-}$ brary, University of California, Berkeley, CA 94710.

\section{Editorial Boards}

Choice Editor: Patricia Sabosik, Choice, 100 Riverview Center, Middletown, CT 06457.

College \& Research Libraries Editor: Charles Martell, University Librarian, California State
University, 2000 Jed Smith Drive, Sacramento, CA 95819.

College \& Research Libraries News Editor: George M. Eberhart, ACRL/ALA, 50 E. Huron St., Chicago, IL 60611.

Non-Serial Publications Editor: Mary Ellen Davis, ACRL/ALA, 50 E. Huron St., Chicago, IL 60611 .

Publications in Librarianship Editor: Jonathan A. Lindsey, Coordinator of Library Affairs, Baylor University, Waco, TX76798.

Rare Books \& Manuscripts Librarianship Editor: Alice D. Schreyer, Head, Special Collections, University of Delaware Library, Newark, DE 19717.

\title{
SPICE programs in Nebraska
}

\author{
By Gail Egbers
}

Library Instruction Coordinator

University of Nebraska-Lincoln and Joan Giesecke

Associate Dean of Libraries

University of Nebraska-Lincoln

\section{Minority high school students in a university setting.}

$\mathbf{T}$

he University of Nebraska at Lincoln

(UNL) held its second annual SPICE (Summer Pre-College Instruction and Career Experience) program in June 1989. The week-long program, coordinated by the university's MultiCultural Affairs Office, is designed to promote the value of higher education to tenth-and eleventhgrade racial minority students in Nebraska by giving them a sense of what a college education involves. It is also designed to provide information about career opportunities in the various disciplines. This year the libraries joined with eight other colleges, four departments, and two vicechancellor's offices at UNL to provide programs and workshops for the students. In 1988 students who would be entering the tenth grade attended the SPICE program. In 1989, these same students were invited along with a new group of tenth graders. The sixty-one students in 1989 were divided into two groups by grade. Each group included an equal mix of racial minorities, as well as an equal number of males and females. These Nebraska students came from a wide variety of backgrounds. Some were from Omaha and Lincoln, while others were from rural areas. They also had different levels of academic achievement and school involvement.

Planning for the program began in February 1989. Campus-wide SPICE meetings were held monthly with the representatives of each college involved in the program. Each college or department could choose to conduct either a three-hour 


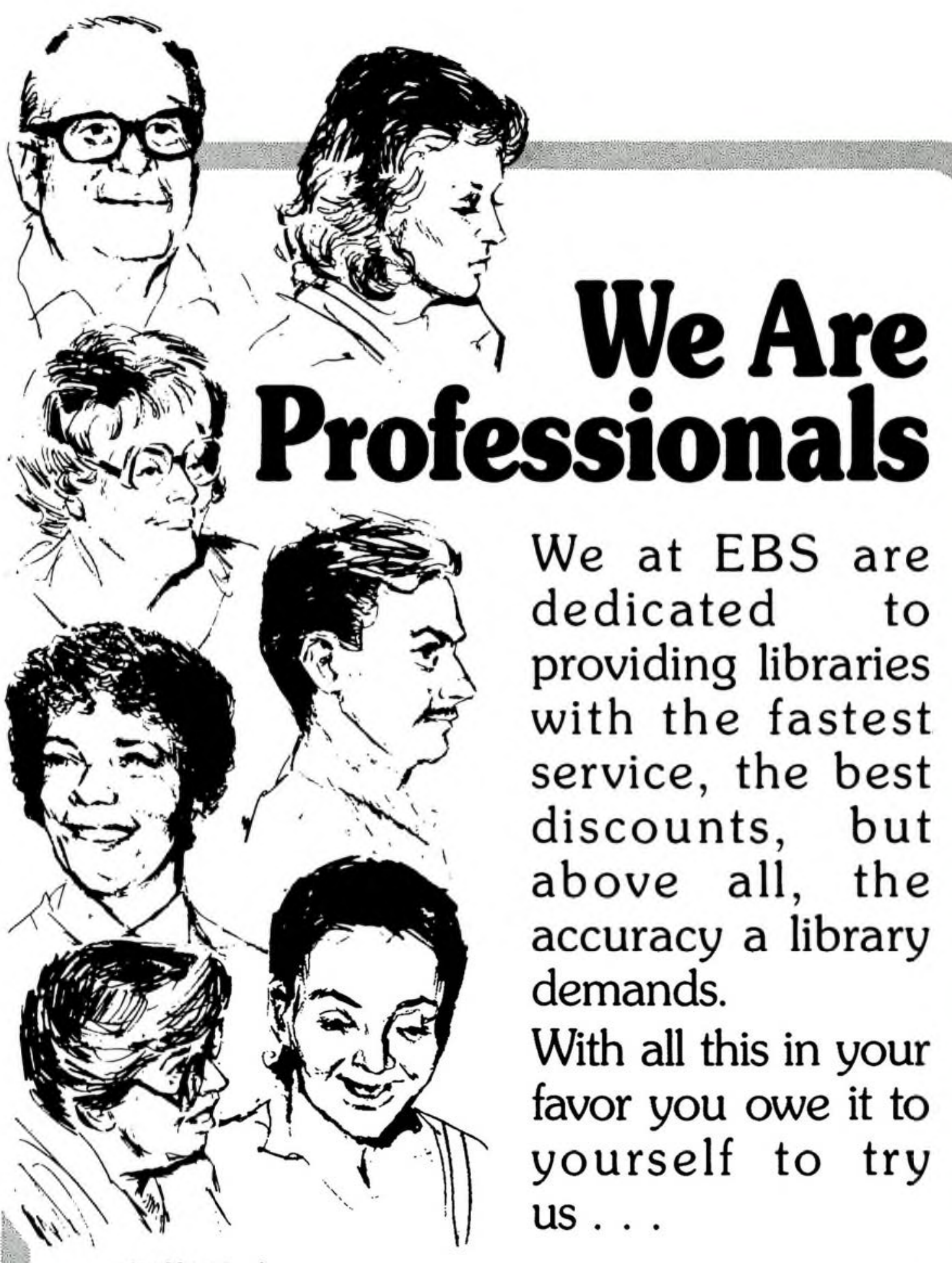

IIII|IIIIIII

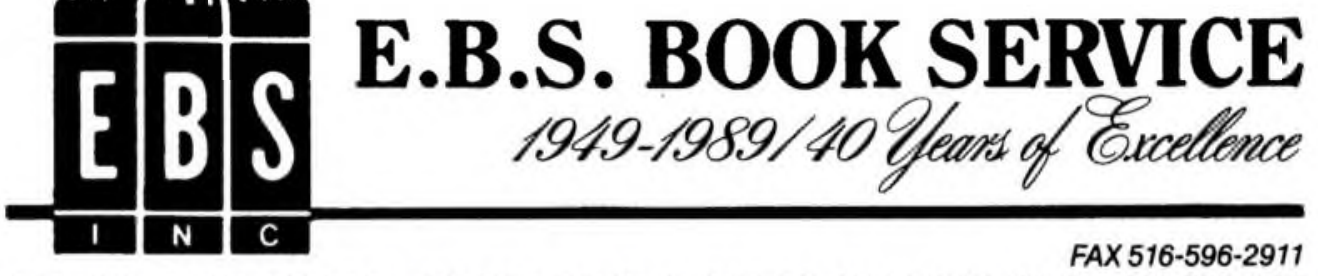
E.B.S. INC. BOOK SERVICE - 290 BROADWAY, LYNBROOK, NEW YORK 11563 - 516-593-1207 
program or a six-hour event, and could choose to work with the new students, the returning eleventh graders, or both groups. We presented our ideas at the meetings and gave each other feedback on the plans. We were given information about the students and about the variety of recreational and educational activities scheduled for the week's events. Schedules were carefully synchronized as the students were busy from 6 a.m. to 10 p.m. each day.

The libraries chose to present a three-hour workshop for the 28 returning eleventh-grade students. We felt that these students would be more interested in using the library and might have more of a need to do library research in their school work. Since this was our first year of designing a program for minority high school students, and because we wanted to include library instruction in our program, we conducted a literature search to discover information on library instruction for racial minority students. The results were surprising to us. Overwhelmingly the articles were on foreign students in the United States.

Since there was very little written about library instruction geared to domestic racial minorities, particularly for high school students using a university library, we decided to try modifying our basic bibliographic instruction program for freshmen. We also chose to divide the students into groups of seven and to not conduct a formal bibliographic instruction session for them. We wanted a program that was informal, and included hands-on activities for the students. We began with the research strategy flow chart and self-paced workbook that we use for many freshmen instruction classes. We put together four different workbooks with a generic flowchart, a topic-specific flowchart, maps, glossary of library terms, and explanations of the Library of Congress subject headings. We chose four topics pertaining to different cultures (Afro-American, Hispanic, Native American, and Asian-American) and inserted these into the flow chart. We included questions that required the students to use the Library of Congress Subject Headings, card catalog, Wilson indexes, PAIS, and the government documents CD-ROM index to find information on these topics. We did not expect the students to read all of the materials while theywere at the library but hoped they would use the workbooks as resources when they returned to their high schools.

The final plans included a brief tour of the library, the exercise of doing research using the workbook, and a wrap-up session to discuss the research process. We also made up packets for the students which included handouts on finding scholarship information and facts about library careers.

Volunteers were recruited from all of the library staff to serve as group leaders. Public and technical services faculty and staff volunteered. We decided to use six volunteers so that we could have four group leaders and two staff to help with the CDROM machines. The volunteers were to give the students any help they needed while doing the workbooks or working on the CD-ROMs. The volunteers had one three-hour training session and one last-minute discussion session. Some of the volunteers had not used periodical indexes, so our training session included basic library instruction as well as tips and ideas on working with the students. Follow-up memos were sent to the volunteers to keep them apprised of schedules and to give presentation hints that we thought might be useful. We also held an All-Staff meeting to introduce the SPICE program to the library staff and to help raise their consciousness about the University's programs for racial minority students. Vaughn Robertson, coordinator for the SPICE program, addressed the staff, providing them with information about the program and helping to explain how the campus was involved in recruiting racial minority students. His talk set a positive tone for the program and helped to prepare staff for the onslaught of the high school students. Now, we felt we were ready for the students.

When the students arrived at 8:15 on Thursday morning, they were quite sleepy from a late movie the night before and were functioning on about five hours of sleep. They were also worn out from the previous four days of activities. These problems made it difficult for us to keep their attention. At first they did not want to walk around for the tour but, once they got started, they found the automated circulation system, the microforms area, and the maps intriguing. When they started to work on their workbooks in their groups they seemed reluctant to do anything. As the exercise progressed, some of the students got veryinvolved and it was easy to see they thought it was interesting. The favorite part for everyone was using the CDROM machines.

We asked the students to fill out an evaluation form at the end of the program and, given the adverse conditions of working with very tired students, we were reasonably pleased with the results. As was seen in the overall positive evaluation the students gave to the SPICE program, most of the students felt the information we gave them will be useful and they said that most of the information we presented was new to them. Although the students did not want to discuss their experience in using the library they did suggest that we change the topics for the research. They wanted us to use topics of more interest to them such as drugs or alcohol abuse. They also suggested we spend more time explaining what goes on in a library and less time actually using the collections.

We are now incorporating the students' com- 
ments and our own ideas into planning ways to improve the program for next year. We will scale down the research and have the students answer only one question per index rather than several questions. We will also use more library staff as volunteers. More help was needed while the students were doing the workbooks. Groups of three or four would have been easier to manage. Since the students are interested in computers we may add some time in technical services so they can see how we use computers in our work.

The idea of preparing promising students for what lies ahead of them in college is quite exciting.
We hope that these young people liked what they saw on the campus as a whole and will apply to the university. We especially hope that the students took home some things that will help them survive in high school and will prepare them for college. We also enjoyed the opportunity to work with other university faculty and staff in providing a service program. SPICE was obviously a team effort. We became better acquainted with our colleagues and learned more about each other's recruiting programs. We foresee that the libraries' participation in SPICE will be a regular summer event.

\section{ACRL executive summary}

The weeks between August 19 and September 8 were internationally significant for ACRL. We were a presence at IFLA and we held our second overseas meeting. All of this international activity, added to the report of the ACRL Task Force on International Relations, has set us thinking more seriously about our role in global affairs. This issue of $C \mho R L$ News contains several items of international interest, and the ACRL Executive Committee will devote some time to the subject at its fall meeting, November 10-12.

\section{Professionaldevelopment (ACRL GoalI)}

IFLA. ACRL was a significant presence at the IFLA meetings in Paris in August. Choice and ACRL shared the ALA booth, where JoAn Segal held forth part of each day in French and Spanish. The Conference included several different sessions on university libraries, with ALA representativesincluding Joe Rosenthal, Marilyn Sharrow, and Hwa-Wei Lee on the Standing Committee on University and General Research Libraries. The International Association of Technological University Libraries (IATUL), which includes a substantial North American contingent, met for an information-sharing session. A Seminar on Performance Measures for Academic Libraries used nominal group process to derive a list of the measures considered most important by the fifty participants from many nations. This was an election year: Hans-Peter Geh was re-elected president and U.S. delegate Bob Wedgeworth was re-elected to the Executive Board. Although many U.S. institutions are members, not all of them sent a voting representative or proxy. At its fall meeting, the ACRL Executive Committee will be considering its role in the IFLA appointments process.

RBMS Conference. The Rare Books and Manuscripts Section's conference, "Markets for Books and Manuscripts: The Trade in Antiquarian Materials Past and Present, "was held September 5-8 at Newnham College, Cambridge University. About 275 participants attended, more than one-third from outside the United States. The opportunities for exchanges with colleagues across the ocean, the excellent papers, Book Fair, and other occasions to meet book dealers from Great Britain, were further enhanced by tours of many of the libraries of the Colleges of Cambridge University.

$N E H$. The ACRL/PLA proposal to the National Endowment for the Humanities was not funded. However, we have made some revisions in light of the panel's comments and have resubmitted a proposal for a series of workshops on humanities programming.

\section{Enhancing library capability (ACRL, Goal II)}

The ACRL Academic Library Statistics Committee mailed its questionnaire to non-ARL university libraries. The Committee had recommended, and the ACRL Board approved, collection of data in odd-numbered years, since the U.S. Department of Education's Integrated Postsecondary Education Data Service (IPEDS) will collect in even-numbered years.

\section{Advocacy and liaison (ACRL Goal III)}

In September the Middle States Association held its training sessions for site visitors. Library and learning center directors who will serve on visiting teams were encouraged to heed the new "Characteristics of Excellence in Higher Education: Standards for Accreditation" document, which specifies that bibliographic instruction is essential. A report from this meeting will be published in the November issue of C $₫ R L$ News. Handouts at the session included ACRL's three 
standards (college libraries, university libraries, and two-year programs) and the Model Bibliographic Instruction Statement.

\section{Strategic management directions}

Leadership enhancement. All ALA division vicepresidents/presidents-elect participated in the fourth annual Division Leadership Enhancement Program in Chicago September 15-16. Group members had the opportunity to get to know each other and to lay the groundwork for cooperative endeavors. They heard a great deal about ALA and how it operates, and took the opportunity to set up working relations with their division staff members. Barbara Ford, speaking before the group, emphasized ALA-wide cooperation and offered her information literacy theme as a possible common thread of interest.

Membership survey. Research USA has mailed out an ACRL membership survey to a select sample of our members. The Planning Committee will use the results in revising the Strategic Plan and it will help in reviewing our publications and education programs.

The budget. The final budget submitted to ALA Planning and Budgeting includes revenues of
$\$ 865,470$, plus $\$ 1,453,960$ for Choice. Expenses of $\$ 923,150$, plus $\$ 1,469,793$ for Choice are budgeted. The deficit for ACRL is $\$ 57,680$ in the 1990 fiscal year. The Choice deficit will be $\$ 15,833$. The year-end fund balance will be approximately $\$ 494,300$, or about $6 \%$ above the mandated $50 \%$ level.

Personnel. Randy Meyer took up the position of administrative secretary to Mary Ellen Davis on September 15. Randy, a library school student at Rosary College, had a previous assignment in ALA's Office for Library Outreach Services. Dawn Jacobson, who had worked half-time for Mary Ellen throughout her college career, graduated from the University of Illinois at Chicago and has taken a full-time position in the business world.

Cynthia Taylor, who has been working half-time for Alia Al-Taqi on membership and chapter activities, moved to full-time status and took on administrative secretary duties for JoAn Segal.

Cheryl Robinson-Smith has returned from maternity leave to her duties as assistant editor of $C$ \&RL News. Pam Spiegel, who had temporarily taken over that position, has left as editorial assistant to go on maternity leave. Karen Christopher is now serving as editorial assistant.-JoAn S. Segal, ACRL Executive Director.

\section{... \\ News from the Field}

\section{Acquisitions}

- Boston College has acquired the papers of the noted penologist, Howard Belding Gill, best known for his work at the NorfolkPrison Colony, a unique institution that housed inmates in dorms instead of cells, and had its own workshops, stores, and chapel. The Gill collection consists of over 110 linear feet of manuscripts, photographs, and audio discs, as well as a large number of charts and graphs pertaining to the Norfolk Colony. The collection was donated by Benjamin Gill, Howard's oldest son and executor of the Gill estate.

- McMaster University, Hamilton, Ontario, has acquired the papers of Clarke Irwin, Inc. (1930-1983), one of Canada's major publishers. The firm published such major authors as Robertson Davies, Emily Carr, and Tyrone Guthrie, and published standard texts such as Living Latin and Pirates and Pathfinders. The archive consists of approximately 90 linear feet and includes author correspondence, administrative and business records, editorial files, information on marketing and promotion, and photographs. The most extensive and valuable section is the editorial files, with records of correspondence with authors, reports on manuscripts, royalty and publications statements, and permissions for individual titles.

The University has also acquired the archives of Peter Martin Associates, a small publishing firm founded in 1965 and run for 16 years. The collection of correspondence, business files, promotion and subsidiary files extends to 14 linear feet and concerns authors such as Janet Lunn, Fredelle Maynard, and David Louis Stein.

- Northern Illinois University's Founders Memorial Library, DeKalb, has acquired Alice Lohrer's personal collection of over 325 books, pamphlets, and magazines for children. The collection, which spans two centuries of children's litera- 